\title{
Is There a Specific Accrual Basis Standard for the Public Sector? Theoretical Analysis and Harmonization of Italian Government Accounting
}

\author{
Fabio Giulio Grandis ${ }^{1}$, Giorgia Mattei ${ }^{2}$ \\ ${ }^{1}$ Associate Professor of Public Administration Economics, Roma Tre University, Rome, Italy \\ ${ }^{2}$ Candidate in Economy and Management, University of Urbino, Urbino, Italy \\ Email: fg.grandis@studioferrari.com,giorgia.mattei@uniurb.it
}

Received September 10, 2012; revised October 12, 2012; accepted October 20, 2012

\begin{abstract}
This paper aims to analyse the principle of accrual accounting when applied to non-business-oriented companies, including most general government bodies. The analysis is carried out by referring to concepts that are well-established and firmly anchored to the "history" of accounting and which, today, allow us to define the principle of accrual accounting for "non-business" activities differently to that applicable to profit-oriented companies. This also gives rise to a different interpretation of the economic result. This work subsequently provides a "fieldwork" analysis of how accrual accounting has been introduced in the Italian public sector through an on-going accounting harmonization project. Finally, this paper offers a critical examination of the current accrual basis recognised by the International Public Sector Accounting Standards (IPSAS), as compared to its theoretical definition. The conclusions of this paper support the theory that the IPSAS can contribute to the current harmonization of Italian government accounting, but also reverse.
\end{abstract}

Keywords: Public Administration Accounting; Principle of Accrual Accounting; Accounting Harmonization; International Public Sector Accounting Standards Board (IPSASB)

\section{Objectives and Research Methodology}

Up to 2002, the work carried out by the International Public Sector Accounting Standards Board (IPSASB, formerly PSC, Public Sector Committee) was that of adapting the accounting principles of the International Accounting Standards (IAS) to the public sector. Subsequently, IPSASB began to develop a number of specific accounting principles for cases in which the IAS princeples could not apply-hence the peculiarity of the public sector. For example, the IPSAS 23 principle on "Revenue from Non-Exchange Transactions" was published in December 2006. During this second phase, IPSASB's strong attachment to the IAS framework conditioned its choice to extend the so-called "accrual basis" principle of accounting, applicable to private companies, to the public sector $[1,2]$.

This paper's first objective is to analyse whether the accrual basis principle set out in the IAS framework can be implemented in non business organization without any modifications, or whether it will have to be undergo the typical adaptations or tailoring required for the public sector.

This paper's second objective is to examine how the accrual system has been introduced in the Italian public administration over the last 20 years and, in particular, to study the recent process of accounting harmonization of public financial statements, which is provided for in the Italian Constitution.

The methodology used in this paper is both deductive and inductive. A deductive analysis has been applied mainly in relation to this paper's first objective. In that regard, this paper offers a detailed and doctrinal research on the topic, delving into the specific peculiarities of the public sector, which is characterised by its non-businessoriented nature, its specific funding regime and a frequent lack of a market price for the services it provides.

Conversely, an inductive analysis has been applied mainly in relation to this paper's second objective. By analysing concrete cases, the provisions on the implementation of accrual systems and the effective means of implementation of such systems, one can assess to what extent the doctrinal analysis is indeed accurate.

Such analysis highlights the real difficulties that public bodies and administrations face when applying the principle of accrual accounting adapted to non-business-oriented companies. The reasons for such difficulties are two-fold: the first reason, which can be extended to an 
international level, relates to how the economic result isinterpreted according to the accrual accounting principle adopted; the second reason is specific to all public administrations in those countries where the budget plays a strong “authorizing” role.

The turbulent context in which European public administrations operate would prompt a traditional accounting system being implemented alongside one that can maintain economic stability over time. However, it is also true that economic stability for a profit-oriented company is very different to that of a non-business-oriented entity, such as general government bodies_-at least the Italian ones.

If we consider other international scenarios, the assumption that all of the most economically advanced countries have adopted, or are about to adopt, the "full accrual” accounting system, is clearly put into question.

A new interpretation of the accrual accounting system aimed at the public sector is likely not only to revive the modernisation of public accounting systems, but also to avoid any regrets in switching from the current public accounting system to one with a focus on accrual basis accounting $[3,4]$.

\section{2. "Historical" Relevance of the Economic Analysis of Public Administrations}

Nowadays, public administrations are mainly made up of non-business-oriented bodies which carry out a number of activities that are similar to those of "business-oriented" companies.

In fact, it has been observed [5] that public administrations also carry out business-like processes, have their own asset management activities and carry out profitable corporate transactions. These activities, however, play an instrumental role with respect to the all other activities which such public bodies carry out in order to reach their institutional, political and social goals.

In Italian general government bodies, economic relevance gained notoriety only in the 1990s, notwithstanding the fact that a distinguished scholar had anticipated its importance by more than a century $[6,7]^{1}$.

In the past, management analysis was limited to financial and monetary aspects, following a "kameral" accounting system [8]. This approach, adopted due to traditional public administrations, revealed its shortcomings when the public sector began to adopt increasingly complex production processes as a result of public economic intervention and the direct fulfillment of the collective administration needs.

Such an approach has given rise to a number of technical and administrative difficulties, many of which are

${ }^{1}$ In the $19^{\text {th }}$ century, the most prevalent scholar of Italian public accounting was definitely Giuseppe Cerboni. still relevant today $[9,10]$, and the most important of which relates to corporate asset fluctuation.

Net asset maintenance has therefore become the minimum requirement for a company's "survival” and sustainability; without this condition, the public sector would suffer "a continuing pathology" [11] $]^{2}$ resulting from management trapped in an "irreversible coma”.

Net asset conservation is to be interpreted dynamically, perhaps as a "re-conversion" of assets according to public needs, which change through time and in accordance with the main political class in power.

A management analysis based solely on financial aspects is now considered to be insufficient.

In Italy, the reform of the public accounting systems introduced the requirement-for the public Administration-to also carry out an economic and asset management analysis but different accounting models [12] prevailed. Such models reflect two distinct approaches, which are also found in international doctrine:

1) The first approach completely abandons "traditional" public accounting in favour of the same economic survey models used by companies [13-17].

2) The second approach is based on different integration models for both financial and economic surveys $[18,19]$.

The choice of one approach over the other fuels school-arly debates and clarifies the rationale behind several accounting provisions applicable to the various areas of the public sector.

In any case, an economic analysis of management has become both necessary and inevitable. Nonetheless, in order to understand the actual relevance of such information, it is important to examine how the accrual basis system applies to non-business-oriented companies, as opposed to the typical profit-oriented companies that are active on today's markets.

\section{The Accrual Basis in Non-Business-Oriented Companies}

In most public sector entities, the production cycle of a service provided only justifies costs and charges. Only rarely are adequate earnings made on a service, since the entire business process is not aimed at sales but, rather, at meeting the needs of a community.

\footnotetext{
${ }^{2}$ Amaduzzi very aptly points out: “manifestazioni numerarie, imposte dalla continuità della vita aziendale, possono anche richiedere lesioni al potere di generazione di ricchezza che l'azienda di erogazione abbia. E allora se non si verificasse una ricostruzione delle perdute forze economiche, l'azienda sarebbe destinata alla cessazione del suo unitario processo, o alla continuazione patologica della sua vita, quando l'azienda fosse perenne per natura". It is assumed that he term "long-lasting company" used by the author refers to public sector companies that, as such, cannot go bankrupt. Nevertheless, in today's reality, such public sector companies can have their goods confiscated and auctioned, can be placed under temporary receivership or, potentially, be absorbed by a higher-level administrative body.
} 
Furthermore, most of the revenue which funds the factors of production is, contrary to costs and charges, entirely independent from the volume of the activity carried out. For example, a state or government grant or a mandatory contribution towards a public sector entity is often awarded notwithstanding the quantity and quality of the services provided. In these cases, the revenue perceived is not consideration for a specific service provided, but it generally falls within a general institutional objective.

Thus, in order to fully understand the differences between the economic management of a business-oriented company and that of a non-profit-oriented one, it is necessary to distinguish management details taken from the economic results and based on the following points: earnings and costs, implying an underlying exchange of goods and services; revenue and charges, that do not imply an exchange transaction, but relate to other unilateral acts-be they casual, voluntary or compulsory; these would include, for example, obtaining a contribution in cash or in kind; an extraordinary variation in the value of assets; endowments and donations; taxes and levies, etc.

If we look at needs fulfilled of services provided, we can find the different public Administration structures. These structures, in detail, are:

1) Specific and divisible services that are individually requested; Figure 1.

2) General and indivisible services that is generally requested; Figure 2.

3) Other typologies of contribution provided Figure 3.

In the first category, we find the production inside public Administration. It will be necessary to sustain some costs for the acquisition of production factors. The latter will be put through the operating cycle. This processes results in individually requested services, which generate earnings. These earnings will be reused to sustain costs.

We can identify an exchange transaction both from costs and earnings. This specific accrual basis standard is also found in business organization.

In the second category, we can also find a production. It will be necessary to sustain some costs for the acquisition of production factors that will be put through the operating cycle. This processes result in collectively requested services. Revenues come from higher Administrations. The revenues will be used to sustain costs. We can identify an exchange transaction from the sector costs and non-exchange transactions from the revenue sector; in this case, we think that it is more difficult to implement the "traditional accrual basis".

In the third category, public Administration revenues come from higher Administrations, which are distributed in various modalities (for example: scholarships, unemployment benefit, etc.). These are charges that the public
INDIVIDUAL REQUESTS=SPECFIC AND DIVISIBLE SERVICES

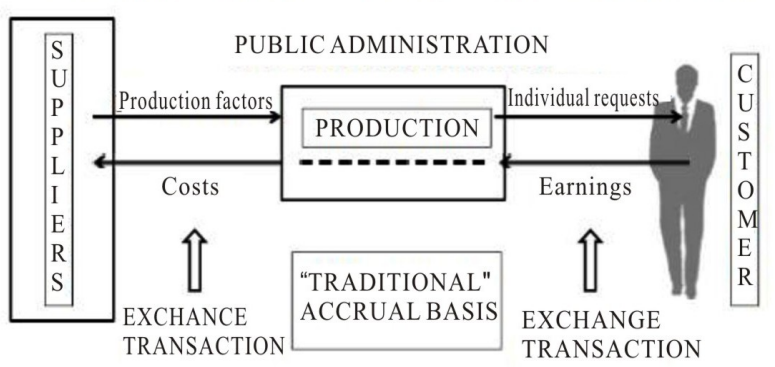

Figure 1. Specific and divisible services.

CENERAL REQUESTS=GENERAL AND INDIVISIBLE SERVICES

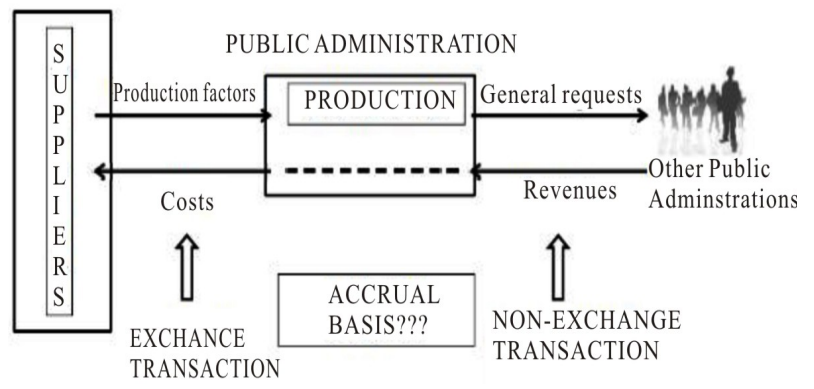

Figure 2. General and indivisible services.

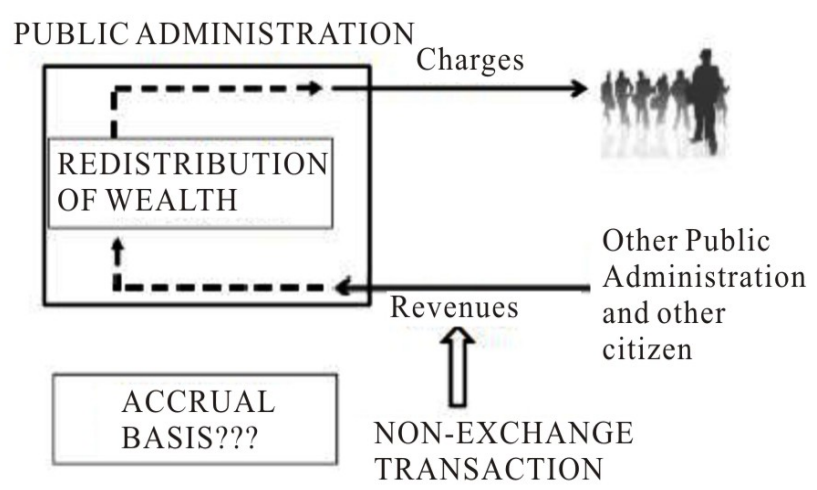

Figure 3. Other typologies of contribution provided.

Administration sustains for the community. In this case we have only non-exchange transactions and, for this reason, is more difficult to implement the "traditional accrual basis".

All administrative facts tied to the economic management of a company can be sub-divided according to by their effects on one financial year instead of another. The costs and earnings, and the charges and revenue are recorded every calendar year on the basis of assumptions on the "causal link" between positive and negative economic elements. It is thanks to this causal link, called "accrual basis", that we can measure asset variations and its respective economic result for the year.

However, the "causal link” is not only extremely dif- 
ferent, but literally inverted $[20]^{3}$ when comparing the dynamics of non-business-oriented companies and profit-oriented ones.

Indeed: in profit-oriented companies, the costs are borne in order to make earnings; the company's main goal is to increase the margin between costs and earnings. in non-business-oriented companies, the opposite occurs: revenue is obtained, often in a compulsory manner, to bear costs and charges needed to reach social, political and institutional goals; the volume of revenue and earnings should represent the maximum limit of costs and charges; in the medium-to long-term, there should be no significant or stable margin between positive and negative economic elements.

The notion of "accrual basis" therefore takes on a particular meaning when it is applied to non profit-oriented companies and, in particular, to public administrations. When the accrual basis concept was applied at the non-business organizations, this notion takes a special connotations, particularly as applied at the public Administration.

Asset management and business activities find their raison d'etre in non-profit-oriented companies only inasmuch as they generate positive net equity, which, seen as a "means", is subsequently "used" to reach an institutional goal.

It is absolutely clear, in fact, that a business activity carried out by a company in loss would have a negative effect on its delivery process. This is due to the fact that a public body, given its unitary character, should cover the losses even where this is to the detriment of the very social needs for which it was created.

It follows from the above that the economic analysis of the management of a public sector entity requires that, as a preliminary step, a distinction be made between events that are directly linked to a market exchange transaction

\footnotetext{
${ }^{3}$ The different notions of accrual basis can be noted by the following comments by P. ONIDA: "But the revenue and expenses of a commercial business cannot be assimilated, respectively, to earnings and costs of an production company for the market exchange. In this company the costs, or better still, complex data of costs - are usually borne on the assumption that they will bring about earnings [...]. However, in a service company, the provision of services and the incurring of expenses, i.e. the outgoings, are not stimulated by potential earnings relating to such outgoings, but rather to satisfy the needs of the entity to which the company belongs. It is also true that the volume of revenue influences expenses and that the means at a company's disposal affects the propensity to consume, and its increase seems to cause and stimulate needs, especially those that are more superficial".

${ }^{4}$ The difference between services on "individual request" and on "collective request" is well-known. The former are particular and divisible services, i.e. services that satisfy specific needs and for which it is possible to quantify the service rendered to the individual beneficiary. The latter are general and indivisible services, i.e. services of collective interest and for which it is not possible to quantify the benefit provided to the user. Clearly, only the services on individual request can be managed in accordance with a business regime, i.e. by requesting specific consideration for the service, regardless of whether the amount of such consideration is regulated by market prices or reflects a political price.
}

and those that are not, by virtue of their social objectives ${ }^{4}$.

In the former, the accrual basis for income and expenses can be traced back to the notion used for companies, i.e. income is distributed to a financial period on an accrual basis when an exchange has taken place, in other words where a transaction such as a succession, an asset or a service has been completed in all its production cycle; expenses are linked to the income for which they were incurred. The correlation can therefore be deducted analytically and directly as a result of a cause and effect. When there is no such causal link, the correlation can be made by reference to the functionality or usefulness from a rational and systemic point of view (for example a time basis) or when utility and functionality of costs is lacking.

In any case, were it is feasible to gain earnings, on a synallagmatic basis, notwithstanding its political price, the aforementioned principle becomes entirely applicable and must be referred to when defining the economic components of a financial period.

In the latter case, and thus for most public sector entities, it is necessary to consider the accrual basis directly in relation to the provision of social benefits and services rendered "outside" market rules i.e. where there is no sales transaction.

Revenue for a public sector entity is not usually related to the volume of institutional activities carried out (take, for example, all taxes and all financial contributions from higher administrations, etc.). Rarely do these constitute consideration for the granting of goods or services. In other words, the synallagmatic connection between income and expenses in these context wanes, whilst revenues and charges follow asynchronously. This therefore implies that, while income derives from costs-as a result of the production and sales process-revenue may have nothing to do with charges: the body that provides the revenue need not be that which benefits from the provision of goods or services.

Furthermore, this highlights the public sector's duty to redistribute national wealth.

The amount of costs and charges is closely related to the amount of institutional activities carried out, since one generates the other. Following such logic, revenue is obtained by virtue of a "formal commitment", or by a "solemn promise" to use it to cover the costs and charges necessary to carry out the required social functions.

Such "formal commitment" and "solemn promise" are contained in the annual budgets which thus become not only the legal bond which regulates the relationship between individual public administrations and their government entities, but also - on a business level-represent the main element when identifying the correlation between cause and effect of revenue and management costs and charges.

The legally binding requirement for public administra- 
tions to budget and management forecasting can now be seen in light of its unavoidable managerial aspect, since the significance of economic analysis would be compromised without them.

In fact, in business, management forecasting is necessary and appropriate, but not essential; in this context, “corporate governance" works "rationally" [21] expecting earnings as soon as costs are incurred; the economic result for the years is relevant regardless of whether any management planning has taken place.

In public administrations, on the other hand, the expected profits must be identified and agreed upon before any costs are incurred and, more importantly, before the revenue has been collected. A causal link must therefore be established in the planning phase so as to allow the economic result to be of greater informational value in indicating management progress. In this case, a net deficit could also be the result of a conscious and express decision [22].

Furthermore, costs and charges must be considered, as a rule, on an accrual basis-not when the corresponding earnings are made, as is expected for profit-oriented companies-but when the following two conditions are met: production cycle of goods and services is over; the service was allocated.

There is a transfer of property rights as a result of an individual request, in the case of goods or services, or the goods or services become a public benefit in the case of social and service activities provided on the basis of a collective request.

The participation of the costs and charges in the production and distribution cycles takes place when: the costs incurred in a financial year by a company relate to items which are not longer relevant by the end of that financial year, or their future relevance cannot be assessed or calculated; the accrual basis of costs can also be determined on the basis of cost flow forecasts or, failing a more direct link, of the repartition of the long-term utility or functionality from a systematic and rationale basis (for ex. amortisation); the potential social utility of the factor of production which incurred costs in the previous financial years is lower or can no longer be assessed; is irrelevant the relationship to the productive process or utility allocation on a rational and systematic basis.

There are specific rules concerning the survey of costs concerning long-term activities, namely the production of goods and the provision of services whose productive process goes beyond a financial year.

Revenue, as well as all the positive economic components provided by non-exchange transaction, must be linked to the costs and charges of that financial year. That link, which is opposite to that concerning income and expenses, represents a fundamental corollary to the principle of accrual accounting for facts of management which characterise the activities of non-profit-oriented companies. It is therefore essential that expenses in a financial period, whether definite or presumed, be set against the respective income. Such a link can be achieved: by a causal link between income, costs and charges. The link can be made analytically or directly (for example: fund-specific taxes, tied loans, entailments, etc.); by the direct allocation of income to the financial statement of a financial period. This can be time-related (for example, year-based taxes) or disjointed in the cost/taxes correlation (for example, income from gains); by transferring, from the balance sheet to the income statement, income that was previously obtained but which is linked to one or more activities carried out in that financial period.

In the last example cited above, there is a need to define a specific set of rules in order to properly account for revenue provided to carry out long-term activities. These are, typically, grants given by the State and other government entities.

It becomes apparent that a proper accounting arrangement within a financial statement should reflect the real animus with which such grants are given $[23,24]^{5}$ and, therefore, should take into account the accrual basis used when making the effective animus assessments.

The animus, intention, purpose and reasons for the grant as well as the possible recipients thereof must, in this context, be differentiated on the basis of the role they play in the management of a single public administration.

We can therefore differentiate between grants intended to restore or increase net assets and those intended for “consumption” or, more precisely, for management.

The animus, intention or purpose of the grant is often retraceable to the laws of the individual county or to the motivations of the governing entities that have given the funding. Thus, once the reasons for a grant has been identified: grants that represent a transfer of funds designed to pursue institutional goals in a lasting and sustainable manner are to be considered as an increase in net assets; grants "for management", designed "for consumption” or covering costs and charges of the year's management will converge into the income statement, among the positive items of that financial period; grants that are to cover specific institutional services over a number of years (carrying out public works, long-term research projects, purchasing fixed assets, etc.) compensate the "social” value generated by the public administration by carrying out its activities; in this case, the grants could be

${ }^{5}$ On this point, refer to F.G. Grandis, 1996. Similarly, in the case of businesses, it has been said: Riteniamo che il metodo più corretto per la contabilizzazione dei contributi in conto capitale debba essere scelto facendo riferimento alle finalità e alle peculiarità di ogni iniziativa agevolata, considerando anche le modalità in base alle quali tale iniziativa si inserisce nell'ambito dell'economia dell'impresa che ha fruito del contributo; solo in questo modo può essere valutata la validità di un determinato approccio e l'efficacia informativa del conseguente criterio contabili. 
treated like deferred income i.e. “deferrals”, or accounted for as a specific liability passive entries to be linked to the cost incurred to carry out the activities for which the grant was given, by using the accounting procedure of "sterilization"6.

In the latter case, the grant could represent, on an abstract level, a "ommitment debt" 25] taken against the community for future services to be rendered or, more precisely [26], in the form of "true accrual basis revenues" In this manner, the balance sheet counterbalances a specific funding source with a specific on-going investment, thus highlighting the binding objective of the grant.

In conclusion, a principle of accrual accounting tailored to public administrations does indeed exist. Such a principle, in some aspects, is the opposite of that which applies to profit-oriented companies.

Only in this manner can the economic result for the period of a "non-business" company be of relevance.

\title{
4. The Importance of the Economic Result for the Year
}

The different notion of the accrual basis for public administrations finds a logical, strategic and managerial meeting point with "rofit-oriented" businesses.

The economic result of a profit-oriented business indicates, when positive, that the year has closed profitably, yielding a net earning; conversely, a loss is recorded

\begin{abstract}
${ }^{6}$ The term "sterilization" comes from the fact that, through such an operation, the economic result from costs incurred is sterilized, driven by the same activities for which the contribution was given. For example, in the hypothesis that a contribution has been obtained to cover the entire disbursement for the purchase of fixed assets, they following accounting entries will ensue:

Credits v/funding
Administration

Fixed assets

Treasurer (bank)

Debts v/suppliers
\end{abstract}

When carrying out writing, adjustment and general account closing, the following entries will ensue:

\begin{tabular}{|c|c|c|c|}
\hline Fixed assets amortization & $\begin{array}{l}\text { Fixed assets amortization } \\
\text { fund }\end{array}$ & & 20 \\
\hline Earmarked contributions & $\begin{array}{l}\text { Earmarked contributions } \\
\text { implementation }\end{array}$ & & 20 \\
\hline Income statement & Fixed assets amortization & & 20 \\
\hline $\begin{array}{l}\text { Earmarked contributions } \\
\text { implementation }\end{array}$ & Income statement & & 20 \\
\hline Final net asset & Fixed assets & & 100 \\
\hline $\begin{array}{l}\text { Various Earmarked contribu- } \\
\text { tions implementation }\end{array}$ & Final net asset & & 100 \\
\hline Earmarked contributions & & 80 & \\
\hline $\begin{array}{c}\text { Fixed assets amortization } \\
\text { fund }\end{array}$ & & 20 & \\
\hline
\end{tabular}

As stated above, the effect on the income statement and net asset is immediately deductible.

Naturally, in the hypothesis that the contribution of grants related to assets is not able to fully cover the purchase, the income statement write off must be calculated by applying the same amortization rate to the consistency of the contribution of grants related to assets. when a year is unprofitable.

In public administrations, like in all "non-business" companies, the economic result of a financial period is not viewed in the same manner [27]. In fact, when a particular public administration constantly generates a net surplus, it is considered not to have allocated all of its resources to reaching its institutional goals. Rather, it is considered to be making an undue profit and to be asking citizens to make an excessive sacrifice in light of real needs and the actual services provided.

In fact, such a scenario effectively indicates that resources can be assigned to services through an increase of charges and of costs which relates to: an increase in the number of users and beneficiaries; an increase in the type of services offered; an increase in the quality of services offered.

As an alternative, the net surplus could be placed in a reserve fund in order to address potential situations of short-term deficit [28] $]^{7}$. In fact, in public administrations, there is no payment of dividends to individual citizens.

In any event, should one not want to take any of the steps described above, one could still: lower the prospective political price of the provision of the services in question; request less funding from the State, which can thus allocate such resources to the pursuit of other public policies; return the surplus to the government entities.

A positive economic result of the year is not considered to be a "profit" as it is understood in "business-oriented" companies - It rather acquires the meaning of a "saving" [5] $]^{8}$. Such "saving" is justifiable only in the short-term, provided it does not affect the quantity or quality of the services [29], or if it is used to cover shortterm deficits or fund future services. Instead, it will be seen as a "harmful" saving if it detracts funds from the social objectives sought by the government entity, or if it requires citizens or local councils to provide an excessive contribution for services rendered to the community.

On the other hand, the prolonging of a deficit situation

7“Attraverso la politica del risparmio il criterio informatore del pareggio economico dei risultati di esercizio viene a tramutarsi in una politica di normalizzazione dei risultati di esercizio, che intende, mediante un accantonamento di ricavi di contributi, per fare fronte a maggiori costi di futuri esercizi, a fare sì che nei vari esercizi l'amministrazione non conduca al disavanzo economico, ma a quel pareggio o a quell'avanzo economico che esprima un normale soddisfacimento di bisogni.

La politica della normalizzazione dei risultati economici dei vari esercizi dovrebbe perciò possibilmente consentire il soddisfacimento di ogni nuovo ed eccezionale ordine di bisogni che l'amministrazione aziendale dovesse affrontare: prevedere quelle temporanee impellenti circostanze non economiche che condurrebbero a squilibri se non fossero fronteggiabili, e dovrebbe anche provvedere a quella mutevolezza di forze economiche dell'azienda e dell'ambiente che potrebbe condurre a risultati troppo vari nel tempo".

8“'L'avanzo economico è in sostanza un risparmio, che varrà a incrementare il patrimonio dell'azienda, e a migliorare la sua condizione economica futura. Va, tuttavia, ricordato che l'avanzo economico non deve considerarsi una méta della gestione erogativa, che è in equilibrio, se i componenti negativi sono pari ai componenti positivi, se cioè si manifesta una situazione di pareggio economico". 
would indicate a serious imbalance in the allocation of resources and, rebus sic stantibus, the wish to pursue institutional goals [30] -in other words, the ability to satisfy the future needs of the community, which the local administration was set up to address [5].

In this case, the management variables with which to operate should be, in particular, "internal" ones, namely those that can be amended by means of decisions or actions that are not dependent on any external influence. These relate in particular to: carrying out a radical analysis of efficiency, return and costs; determining the specific needs to be satisfied, some of which may no longer warrant "public" assistance and can, therefore, be managed by the business sector; examining the effectiveness of the services provided. In some cases the fulfilment of needs could even fall below the minimum social necessary needs; thoroughly analysing earnings and revenue by means of, for instance, an increase in the political price of some services; increasing the output amountonly the minimum amount of such output is usually binding-by imposing a "price" that is at least greater than the unitary variable cost, without increasing fixed costs.

A situation could also arise where the resources available are insufficient to achieve institutional goals. The public sector entity is then compelled to obtain more funding from the State or from general government entities, or if it has fiscal autonomy, to increase the tax levy on citizens, thus increasing the tax burden on the community.

However, obtaining greater revenue of this kind should be conditional on the State or government entity bearing this burden expressing a social, political ad macro-economic opinion on this.

In brief, the scalar income statement must be read "the other way round": once the balance statement balances out, the intermediate results, for example EBITD (Earnings before Interest Tax and Depreciation), must be as low as possible and not, as for companies, as high as possible.

The lower the EBITD, the more income has been allocated to covering institutional costs and charges rather than facing extraordinary and unforeseen operations.

Once again the economic logic behind public administrations, as for all non-business organisations, is "inverted" compared to profit-oriented businesses [31].

\section{The Implementation of Accrual Accounting in the Italian Public Sector}

In Italy the accounting system of every public administration is characterised by the legislation applicable in its particular field and the authoritative legal bond sanctioned by the budget forecast. This also weighs heavily on the general principles and the framework that is set for financial reporting.
As a result of accounting reforms implemented between 1992 and 2003, accounting in Italy has been characterised by its ambiguous rules [12] and its heterogeneous application, even among public administrations of the same kind.

Although the analysis below relates only to obligatory financial reports, accounting principles in Italy can be summarized as follows:

1) The state accounting system provides for the drawing up of a "balance sheet"; in 1997 a cost accounting system was introduced, but which does not, however, provide general results or an economic appraisal ${ }^{9}$; the general principles of this system were extended to regional level in $2000^{10}$;

2) Provisions applicable to local authorities (provinces and councils) since 1995 enforce the mandatory "balance sheet" and "income statement" schemes, but leaves to their discretion the ways in which to introduce accrual accounting ${ }^{11}$; on analysis, there are remarkable differences among the accounting systems of over 8000 local authorities, despite the fact that a specific body was set up to draft uniform accounting principles ${ }^{12}$;

3) Since 1992, the accounting method to be used by bodies linked to the National Health Authority (Aziende del Servizio Sanitario Nazionale) is that set out in the provisions of the Italian civil code applicable to limited liability companies, although regional authorities the power to establish more detailed rules ${ }^{13}$; consequently, this has resulted in 21 different legal regimes (19 regions and 2 autonomous provinces) being applicable to 250 public health companies scattered throughout the country;

4) Since 2003, the rules applicable to national institutional entities (welfare entities, research entities, Government entities, national parks, etc.) are essentially analogous to those of local authorities; the rules in fact specify the general accounting principles, including the accrual basis principle ${ }^{14}$.

Based on the analyses carried out, public administrations falling under points (b) and (d) use the "theoretical" accrual basis principle defined in chapter 3 of this paper. This is substantiated by: the latest version of the accounting principles published by the National monitoring centre for the finance and accounting of local authorities

\footnotetext{
${ }^{9}$ L. 94/1997 e D.Lgs. 279/1997, Article 10.

${ }^{10}$ L. 208/1999 and the subsequent D.Lgs. 76/2000

${ }^{11}$ D.Lgs. $77 / 1995$ transposed by D.Lgs. $267 / 2000$. Concerning accrual basis accounting, see Article 232 of the D.Lgs.267/2000.

${ }^{12}$ This organization, called "Osservatorio sulla finanza e la contabilità degli enti locali”, is provided for by Article 154 of the D.Lgs. 267/ 2000.

${ }^{13}$ Lgs. 502/1992, Art. 5. Regional bodies have aligned themselves to these standard with considerable delay and, even now, there are entities pertaining to the National Health Authority that have only formally introduced accrual basis accounting.

${ }^{14}$ See addendum n.1 of the President of the Italian Republic Decree (D.P.R.) $97 / 2003$.
} 
(Osservatorio per la Finanza e la Contabilità degli enti locali), for administrations falling within point (b) [32]; both in the text of the law itself and the technical documentation relating to its publication [33].

Furthermore, when analysing the liabilities in the balance sheet ${ }^{15}$ of institutional bodies, local authorities ${ }^{16}$ and companies forming part of the Italian National Health Authority $^{17}$, one can see how multiannual earmarked provided by government entities are recorded under a specific liability entry. Consequently, in order for such data to be used, an accounting "sterilisation" procedure is necessary, implying the "correlation between revenue and cost" and not the "correlation between cost and earnings".

Recently, within the context of the government accounting harmonization process provided for in the Italian Constitution $^{18}$ after a 2001 amendment, public administrations have had to adopt accrual accounting ${ }^{19}$, in addition to-and not in replacement of-traditional public accounting. Accrual accounting will only be of informational value, providing support to managerial processes, but will be devoid of any legal or authoritative value.

As a result of the aforementioned prescriptive provisions, some common principles of general accounting were set out ${ }^{20}$, Amongst these is the "accrual basis principle", compatible with the results of the theoretical analysis discussed in chapter 3 .

It is in this very context that IPSAS could be particularly useful if they were not the result of a mere unquestioning transposition of IAS but were able to take account of the particular characteristics of public administrations in general and, in particular, those in which the budget still plays a strong "authorizing” role.

\section{The Accrual Basis Principle in IPSAS}

Taking into account IPSAB's strong attachment to the IAS framework, it seems clear how the accrual basis principle $^{21}$ has also become the standard for public administrations that opt for IPSAS.

Paragraph 22 of the IAS framework, entitled "accrual basis", indicates that this basis is useful for the preparation of financial reports. However, it specifies that under this basis, the effects of transactions are recognized when they occur, and not when cash or its equivalent is received or paid. Consequently, these transactions are noted and merged into their corresponding time frame in annual reports.

\footnotetext{
${ }^{15}$ See addendum 13 of the D.P.R. 97/2003.

${ }^{16}$ See model 20 of the D.P.R. 194/1996.

${ }^{17}$ See D.M. 13/11/2007.

${ }^{18}$ Art. 117, item n. 3of the Constitution of the Italian Republic.

${ }^{19}$ Art. 2,item n. 2, point d) of L. 196/2009.

${ }^{20}$ See addendum 1 of the D.Lgs. 91/2011. Similar regulations are contained in addendum 1 of the D.Lgs. 118/2011.

${ }^{21}$ Paragraph 22 of the IAS framework entitled: “Accrual basis”.
}

When comparing this definition with the one provided for in the Italian civil provisions ${ }^{22}$, which provide for an inclusion in the budget of “[...]" period revenues and charges, irrespective of the collection or payment date', no fundamental differences seem to exist between the two. Here we can also see that the basic idea is to establish a link between costs and earnings, therefore establishing that the economic effect of all the period events must be attributed to the relevant financial period and not to that where the corresponding payments are made or received.

In the light of the above, as well as the concept which was developed at length in chapter 3 relating to the impossibility of applying the accrual basis principle tout court to the public sector, it becomes apparent that it is necessary to adapt such a standard to the particular characteristics of public administrations.

The cash basis has always been taken into account by IPSAS, even though it was intended to be a transitional system though which to reach the "full accrual" system [34]. Only as from 2006 onwards [35] did the IPSASBaware of the difficulty of extending all the "private" standards to the public sector-undertake the planning of a specific IPSAS framework in which it would have even been possible to redefine the standard of accrual ba$\operatorname{sis}^{23}$.The last of the four documents issued by IPSASB dates back to January 2012, when the IFAC website published an Exposure Draft and a consultation paper entitled "Conceptual framework for general purpose financial reporting by public sector entities: presentation in general purpose financial reports”.

An analysis of the draft documents pertaining to the IPSAS framework illustrates the well-rooted position that the accrual basis should be used in drawing up public accounts. In fact, one can easily appreciate the main advantages $^{24}$ of using accrual basis for management-related issues. It therefore seems that the findings based on the cash basis provide considerably less information than

\footnotetext{
${ }^{22}$ See Article 2423 bis, Italian Civil Code, point 3.

${ }^{23}$ The expectations of the transactors find their raison d'etre in the frequent misapplication of certain IPSAS principles-especially the one connected to accrual basis accounting-were these may not be applicable to public Administrations. The IPSAS framework elaboration has been divided into four stages. AN exposure draft has been published for each stage: 1) Users, objectives, scope, qualitative characteristics, reporting entity; 2) Elements and recognition in financial statements; 3) Measurement of assets and liabilities in financial statements; 4) Pre-sentation and disclosure.

${ }^{24}$ This statement can be found on the $31^{\text {st }}$ January 2012 IFAC website entry, which says: "Financial statements prepared under the accrual basis of accounting inform users of those statements of past transactions involving the payment and receipt of cash during the reporting period, obligations to pay cash or sacrifice other resources of the entity in the future and the resources of the entity at the reporting date. Therefore, they provide information about past transactions and other events that are more useful to users for accountability purposes and as input for decision making than is information provided by the cash basis or other bases of accounting and financial reporting”.
} 
that obtainable from documents drafted on the accrual basis $^{25}$.

Furthermore, there is no evidence in the IPSAS standards of the need to combine a cash system with accrual basis accounting. However, in Italy many authors [36-40] advocate for an integrated approach to accounting. The coupling of traditional accounting which, by its very nature, is suitable for the financial aspects of management, with full accrual basis which can cover also other financial aspects could provide more information to stakeholders, in particular national governments that have signed international agreements on financial stability.

As reiterated above, accrual basis accounting establishes a correlation between costs and the income resulting from bearing such costs. Such income is recorded under the period in which the transaction takes place. However, this begs the question whether one can apply the accrual principle to entities whose revenue derives primarily from non-exchange transactions? Can this accrual principle apply to entities where most of their costs are unrelated to their income?

Until 2006, none of the IPSAS standards had considered the possibility that income could derive from non-exchange transactions ${ }^{26}$. A non-exchange transaction implies that the income is not linked to an exchange, but to a levy, to a tax or a transfer. In Italy, the financing of the management of the public sector comes mainly from taxes, transfers from other entities or from the payment of services or products rendered. The latter items fall within IPSAS 9, while the others are subject to IPSAS 23.

Taxes are linked to the institutional activities of the entity and to the carrying out of functions that satisfy general societal needs. Taxes, from a legal point of view, can be seen as a forced levy on wealth, while, from an economic point of view, they constitute indirect compensation for providing services to society [41]. Generally speaking, taxes can be collected directly by the individual public entity or can be acquired indirectly by means of transfers from other entities. Based on how they are collected, they can be divided into levies and taxes. Levies are linked to income and assets-and not to the activities of the public body. Taxes, on the other hand, are linked to certain financial operations carried out by the public sector for the benefit of citizens-despite the

\footnotetext{
${ }^{25}$ The necessity of implementing an accrual bass system is highlighted. In fact, on page 3 of the document we find: "Under the accrual basis of accounting, transactions and other events are recognized in financial statements when they occur (and not only when cash or its equivalent is received or paid). Therefore, the transactions and events are recorded in the accounting records and recognized in the financial statements of the periods to which they relate".

${ }^{26}$ The absence of a IPSAS that could acknowledge non-exchange transactions is to be attributed to the derivation of international public sector accounting principles from the private. Due to the difficulty of companies in obtaining this type of revenue, no specific IAS exists.
}

fact that the beneficiary need not be the person having paid the tax.

Transfers are a source of indirect funding because they come from a system of public relations that is established between different government levels and which varies according to the public governance model adopted. Furthermore, no specific correlation exists inasmuch as their entity depends on the organization and provisions which vary from country to country.

The major criticism voiced in relation to IPSAS 23 is the use of the accrual basis - in its traditional sensewhen having to attribute to one period rather than another income obtained from non-exchange transactions.

Based on an analysis of cases in some European countries where IPSAS have been implemented, the principle of accrual accounting is subject to a specific derogation for non-exchange transactions. Such derogation has resulted in the cash accounting principle being applicable in order to allocate all income deriving from non-exchange transactions.

Conversely, under the accrual basis principle, tailored to the public sector, as described in chapter 3 , income deriving from non-exchange transactions could have been attributed not to a cash accounting system, but to the economic relevance of charges for which they were mandatorily taxed.

\section{Conclusions}

In Italy, the public sector accounting harmonization project should have begun in 2001, as a result of the amendment of Article 117 of the Italian Constitution. However, only at the end of 2009 did the Italian Parliament issue the law that marked the launching of such a project, which is currently on-going.

The true incentive for such accounting innovation is the fact that the Italian Government must provide EUROSTAT with the data necessary to check compliance with the stability parameters set by the European Council.

EUROSTAT, and ISTAT in Italy, draw up the data in compliance with Regulation (EC) 2223/1996, more commonly known as "ESA 95", which is a collection of statistical-not accounting-rules. The accounting data under ESA 95 pertains to cash flow and not the principle of accrual basis.

As a result, the macroeconomic tendency at European level is to give increasing primacy to cash flow. Accrual accounting will gain relevance only if it can bring "added value" in terms of informational content to those who govern single public administrations, i.e. at microeconomic and managerial levels.

In order to put this into effect, the principle of accrual basis ratified by IPSAS should not be implemented without question by IAS, but should reflect all the par- 
ticularities and specificities of the public administration.

In fact, the IPSAS' accrual basis standard not consider non exchange transaction effect, such as revenues deriveing from: general and indivisible services supply; other typologies of contribution provided; where the "causal link" between revenues and charges are inverted.

In all likelihood a new definition of the accrual basis principle, applicable to the public sector, would be appropriate, not only to modernise public accounting systems but also to avoid regretting having replaced the current public accounting system with the accrual basis accounting system.

\section{REFERENCES}

[1] S. Newberry, "The Conceptual Framework Sham and Its Support for an Even Greater Sham," Australian Accounting Review, Vol. 3, No. 12, 2002, pp. 47-49.

[2] S. Ellwood and S. Newberry, "A Bridge Too Far: A Common Conceptual Framework for Commercial and Public Benefit Entities,” Accounting and Business Research, Vol. 36, No. 1, 2006, p. 19. doi:10.1080/00014788.2006.9730004

[3] J. Perrin, "From Cash to Accruals in 25 Years," Public Money \& Management, Vol. 18, No. 2, 1998, pp. 7-10. doi:10.1111/1467-9302.00108

[4] I. Lapsley, R. Mussari and G. Paulsson, "On the Adoption of Accrual Accounting in the Public Sector: A Self-Evident and Problematic Reform," European Accounting Review, Vol. 18, No. 4, 2009, pp. 719-723. doi:10.1080/09638180903334960

[5] P. E. Cassandro, "Le Gestioni Erogatrici Pubbliche," Unione Tipografico-Editrice Torinese, Torino, 1960.

[6] G. Cerboni, "Quadro Di Contabilità Per Le Scritture in Partita Doppia Della Ragioneria Generale Dello Stato,” Stamperia Reale, Roma, 1877.

[7] G. Cerboni, "La Ragioneria Scientifica E La Sue Relazioni Con Le Discipline Amministrative E Sociali,” E. Loescher e C., Roma, 1886.

[8] J. Schrott, "Lehrbuch Der Allgemeinen Verrechnungswissenschaf,” Friedrich Rohlicek, Prague, 1856.

[9] F. G. Grandis, "Il Conto Economico Nei Documenti Contabili Degli Enti Pubblici,” Kappa, Roma, 1995, p. 29.

[10] F. Pezzani, "L'evoluzione Dei Sistemi Di Contabilità Pubblica,” Azienda Pubblica, Vol. 18, 2005, pp. 561-565.

[11] A. Amaduzzi, “Aziende Di Erogazione. Primi Problemi Di Organizzazione, Gestione E Rilevazione,” Principato, Messina-Milano, 1935, p. 130.

[12] F. G. Grandis, "Le Ambiguità Nelle Riforme Dei Sistemi Contabili Pubblici,” Quaderni Monografici RIREA, Vol. 47, 2006, p. 10.

[13] B. McCulloc and I. Ball, "Accounting in the Context of Financial Management Reform,” Financial Accountability and management, Vol. 8, No. 1, 1992, pp. 7-12. doi:10.1111/j.1468-0408.1992.tb00137.x
[14] M. Evans, “Corporate Governance,” In: P. Jackson and M. Levender, Eds., The Public Services Yearbook, Chapman and Hall, London, 1995.

[15] D. Heald, G. Georgiou, "Resource Accounting: Valuation, Consolidation and Accounting Regulation," Public Administration, Vol. 73, No. 4, 1995, pp. 571-579. doi:10.1111/j.1467-9299.1995.tb00846.x

[16] T. Mellor, "Why Local Governments are Producing Balance Sheets,” Australian Journal of Public Administration, Vol. 55, No. 1, 1996, pp. 78-81.

[17] J. Guthrie, "Application of Accrual Accounting in the Australian Public Sector. Rhetoric or Reality,” Financial Accountability and Management, Vol. 14, No. 1, 1998, pp. 1-19. doi:10.1111/1468-0408.00047

[18] M. Aiken and C. Capitanio, “Accrual Accounting Valuations and Accountability in Government: A Potentially Pernicious Union,” Australian Journal of Public Administration, Vol. 54, No. 4, 1995, pp. 564-576. doi:10.1111/j.1467-8500.1995.tb01169.x

[19] N. Coon, "Reservation about Governments Producing Balance Sheets," Australian Journal of Public Administration, Vol. 55, No. 1, 1996, pp. 82-85. doi:10.1111/j.1467-8500.1996.tb01185.x

[20] P. Onida, “Economia d’azienda,” Utet, Torino, 1971, p. 20.

[21] H. A. Simon, "Il comportamento amministrativo”, Il Mulino, Bologna, 1958.

[22] M. Paoloni and F. G. Grandis, "La Dimensione Aziendale Delle Amministrazioni Pubbliche,” Giappichelli, Torino, 2007, p. 424.

[23] F. G. Grandis, "Lo Schema Di Bilancio Delle Aziende Sanitarie Pubbliche,” The Community Economic Development Association of Michigan, Padova, 1996, p. 85.

[24] G. Paolucci, “I Contributi in Conto Capitale Nell’Economia Dell'Impresa. Peculiarità Contabili, Prassi Internazionale ed Indagini Empiriche,” Giappichelli Publisher, Torino, 2001.

[25] F. Besta, "La Ragioneria”, Volume I, Seconda edizione, Vallardi, Milano, 1909.

[26] P. Onida, "La Logica Ed Il Sistema Delle Rilevazioni Quantitative D’Azienda,” Giuffrè, Milano, 1970.

[27] J. L. Chan, "International Public Sector Accounting Standards: Conceptual and Institutional Issues,” McGraw-Hill, Milano, 2008.

[28] A. Amaduzzi, "Le Aziende Di Erogazione Primi Problemi Di Organizzazione, Gestione Rilevazione,” Principato, Milano, 1936, p. 123.

[29] L. Hinna, M. Meneguzzo, R. Mussari and M. Decastri, "Economia Delle Aziende Pubbliche,” McGraw-Hill, Milano, 2006, p. 157.

[30] G. Airoldi, G. Brunetti and V. Coda, "Economia Aziendale,” Il Mulino, Bologna, 1994, p. 125.

[31] G. Marcon, “L'evoluzione Delle Teorie Sui Processi Decisionali Delle Amministrazioni Pubbliche, Premessa Per l'Interpretazione Della Riforma Della Contabilità," Azienda Pubblica, Vol. 24, 2011, pp. 207-221.

[32] M. Dell’Interno, “Osservatorio per la Finanza e la Con- 
tabilità Degli Enti Locali, Principio Contabile n.3. Il Rendiconto Degli Enti Locali,” 2008, Par. 111 and 134, in press.

[33] M. dell'Economia e delle Finanze, "Dipartimento della Ragioneria Generale dello Stato, Principi contabili per il bilancio di previsione e per il rendiconto generale degli Enti pubblici istituzionali,” Istituto Poligrafico e Zecca dello Stato, Roma, 2001, pp. 16-17.

[34] S. Pozzoli, "The International Public Sector Accounting Standards between Convergence and Conceptual Framework,” In: M. D’Amore, Ed., The Harmonization of Government Accounting and the Role of IPSAS, McGrawHill, Milano, 2008, pp. 3-18.

[35] A. Bergmann, "Public Sector Financial Management," Pearson Education, Harlow, 2001.

[36] G. Zappa and A. Marcantonio, "Ragioneria Applicata Alle Aziende Pubbliche Principi Contabili,” Giuffrè,
Milano, 1954.

[37] A. Amaduzzi, “Studi di Economia Aziendale,” Kappa, Roma, 1995.

[38] P. Capaldo, "Il bilancio dello Stato nel sistema di programmazione economica,” Giuffrè, Milano, 1973.

[39] E. Borgonovi, "Principi E Sistemi Aziendali Per Le Amministrazioni Pubbliche,” European Garage Equipment Association, Milano, 2005.

[40] G. Farneti, S. Pozzoli, (edited by), "Principi E Sistemi Contabili Negli Enti Locali. Il Panorama Internazionale, Le Prospettive in Italia,” Franco Angeli, Milano, 2005.

[41] E. Borgonovi, "Principi E Sistemi Aziendali Per Le Amministrazioni Pubbliche”, European Garage Equipment Association, Milano, 2002. 